TEME, г. XLIII, бр. 2, април - јун 2019, стр. 527-542

Оригинални научни рад https://doi.org/10.22190/TEME180228032L

Примљено: 28. 2. 2018.

UDK 343.352(497)

Ревидирана верзија: 16. 1. 2019.

Одобрено за штампу: 21. 6. 2019.

\title{
THE IMPACT OF CORRUPTION ON STARTING THE NEW BUSINESSES - COMPARATIVE ANALYSIS OF WESTERN BALKAN COUNTRIES AND DEVELOPED EUROPEAN COUNTRIES
}

\author{
Vinko Lepojević", Maja Ivanović Đukić, Suzana Stefanović \\ University of Niš, Faculty of Economics, Niš, Serbia \\ *lepomilo@yahoo.ca
}

\begin{abstract}
This paper analyzes the impact of corruption on the establishment of new businesses through a comparative analysis of the Western Balkan countries and the developed European countries. The aim of the paper is to examine whether corruption affects the establishment of new businesses, and to identify areas that are important for starting a new business in which corruption is most present, as well as to propose measures that can mitigate the negative effects of corruption and, consequently, make more supportive environments for development of entrepreneurship. Our initial assumption is that corruption has a negative impact on the development of entrepreneurship. In order to check this hypothesis, the method of correlation and regression analysis was applied in research of corruption impact on entrepreneurship development based on a sample of 25 countries. The results of our research have shown that corruption has had a negative and statistically significant impact on the establishment of new businesses. Also, our research has shown that the impact of corruption on the development of entrepreneurship is higher in countries characterized by an insufficiently stable and underdeveloped macroeconomic environment such as the Western Balkans countries, compared to developed European countries. As study has shown, obtaining construction permit and registering property are the areas in which corruption is most pronounced.
\end{abstract}

Key words: corruption, good governance, entrepreneurship, administrative procedures.

\section{УТИЦАЈ КОРУПЦИЈЕ НА ПОКРЕТАЊЕ НОВИХ ПОСЛОВА - КОМПАРАТИВНА АНАЛИЗА ЗЕМАЉА ЗАПАДНОГ БАЛКАНА И РАЗВИЈЕНИХ ЗЕМАЉА ЕУ}

\section{Апстракт}

У овом раду се анализира утицај корупције на покретање нових послова кроз компаративну анализу земаља Западног Балкана и развијених европских земаља. Циљ рада је да се идентификују области значајне за покретање новог посла у којима 
је корупција најприсутнија и предложе мере којима се може ублажити негативно дејство корупције и створити окружење које подстиче развој предузетништва. Полазна претпоставка рада је да корупција има негативан утицај на развој предузетништва. Да бисмо испитали валидност наведене хипотезе, применили смо методе корелационе и регресионе анализе у истраживању утицаја корупције на развој предузетништва, на узорку од 25 земаља. Резултати истраживања показали су да корупција има негативан и статистички значајан утицај на развој предузетништва. Утицај корупције на предузетништво већи је у земљама за које је карактеристичан недовољно стабилан и развијен макроекономски амбијент као у земљама Западног Балкана, на пример, у поређењу са развијеним земљама ЕУ. Као што је студија показала, области у којима је корупција најприсутнија су добијање грађевинских дозвола и регистровање имовине.

Кључне речи: корупција, добра државна управа, предузетништво, административне процедуре.

\section{INTRODUCTION}

Corruption is becoming one of the most current problems around the world which threatens the modern states, in particular countries in transition in which democracy, human rights and market economy are still developing. First of all, corruption slows down social and economic development, leading to increased poverty and inequality (Shaukat, 2004). Also, corruption endangers good governance, undermines the justice system, increases resources the country needs to cope with costs and risks of corrupt behavior, reduces state revenues, thus limiting funds available for public services such as health, education, and infrastructure (Dzhumashev, 2014).

Researchers have noticed, that corruption has not spared any country in the world. But the level of corruption and its distribution are different in some segments of economy as well as in some countries. In this paper, we will investigate the influence of corruption on the development of entrepreneurship, because the impact of corruption on development of entrepreneurship is not much studied in the literature (despite the fact that entrepreneurship is a very important driver of economic development, and corruption is a very serious problem in every society). Also, there is not empirical evidence that the relationship between these phenomena is strong and statistically significant. There are very different opinions in the literature about the impact of corruption on entrepreneurship. On the one hand, there is an increasing number of convictions that explain the extremely negative impact of corruption in all spheres of society, and therefore on entrepreneurship (Avnimelech et al., 2011). It could be explained by the fact that corrupted civil servants, who are motivated by personal interests, make decisions that are contrary to the public interest. This may cause an increase in costs of establishing a new business, the extension of time needed for a new business establishment, encouraging illegal competition, distribution of financial incentives in the wrong 
businesses and in a number of other ways discourage the creation and development of new businesses (Budak \& Rajh, 2011; Hanousek \& Kochanova, 2016). However, there are allegations that corruption can positively affect the establishment of new businesses (Vial \& Hanoteau, 2013), as "grease in the wheel" because it can shorten the time needed for a new business establishment and reduce the cost of establishing a new business (Dreher \& Gassebner, 2013). According to the author of this paper, corruption has a negative impact on the development of entrepreneurship, which is our initial assumption.

In addition, we will analyze the differences in the impact of corruption on the development of entrepreneurship in developed EU countries compared to the countries in transition in the region of Western Balkans. The aim of this paper is to identify areas that are important for starting a new business in which corruption is most present and to propose measures that can mitigate the negative effects of corruption and consequently, make more supportive environments for the establishment of new businesses.

The paper will first give an overview of literature on the impact of corruption on the establishment of new businesses. The second part of the paper will present starting hypotheses and describe models that will be used to check their validity. The third part will explain the methodology and present the results. The fourth part will focus on discussion of results. The final part of the paper will present concluding remarks and recommendations for macroeconomic policy makers.

\section{LITERATURE REVIEW}

Corruption is the abuse of position, power, or procedures to achieve some personal or group interests (Kaufmann \& Vicente, 2005). It implies the violation of the established rules, practices, and procedures, in order to achieve personal gain, to the detriment of public interest (Osuagwu, 2012).

There are different theoretical explanations of the impact of corruption on starting a new business. Some authors have explained corruption only as barriers to starting a new business - "sand-in-the wheel"(Ateljević \& Budak, 2010; Aidt \& Dutta, 2008; Grodeland et al., 2011), while some of them believe that corruption can be a facilitator for a new business establishment i.e. "grease in the wheel" (Méon \& Sekkat, 2010). However, empirical studies have shown that corruption has a negative impact on economic growth including entrepreneurship development. For example, Campos, Dimova, and Saleh (Campos et al., 2010), carried out econometric metaanalysis of data from 41 studies (with 460 estimates), and proved that ultimately, corruption has a negative impact on economic development as well as on entrepreneurship (corruption reduces the overall efficiency of the state and can cause an increase in the cost for establishment of new 
businesses or extend the time required for their establishment). Also, a large number of authors have empirically proved that corruption is negatively associated with private investment and FDI. Limited supply of capital in the country can also be a barrier to starting a new business because potential entrepreneurs cannot provide seed capital (Stefanović et al., 2013).

Avnimelech et al. (2011) proved, on a sample of 176 countries, that corruption has a negative and statistically significant impact on entrepreneurship. Sobel (2008) examined the relationship between the entrepreneurship and government effectiveness and quality of public administration (which is influenced by corruption), on a sample of 48 US states. He showed that a higher level of government effectiveness (which alongside means lower levels of corruption) leads to more capital investment per capita, higher rates of patents per capita and a higher number of start-ups. His research, also, showed that a low level of quality of public administration in some countries (with high level of lobbying, and high level of abuse of the law) creates unproductive types of entrepreneurship. Campos, Estrin, and Porto (2010) focused on a sample of 186 Brazilian companies to examine the key barriers to starting a new business. They proved that corruption is a serious barrier to starting a new business (as for entrance of new firms); even $70 \%$ of surveyed managers believe that corruption is the most serious barrier (among 15 listed factors) for the establishment of new companies.

Therefore, most of the previous empirical studies refer to the fact that corruption has a negative impact on new business establishment. Since there is very little empirical research that has directly linked corruption and establishment of new businesses, the following part will use methods of correlation and regression analyzes to investigate the impact of corruption on the establishment of new businesses.

Also, a previous research (Dreher \& Gassebner, 2013) indicates that corruption indirectly impacts the start of new businesses, through administrative procedures which may differ significantly from country to country. In the developed countries, where law and regulations are most effectively applied, administrative procedures do not have a great influence on starting a new business. Unlike them, in the developing countries and in the countries with a low level of government effectiveness, administrative procedures have a great influence on starting a new business. If administrative procedures increase the cost of establishment, potential founders increasingly use various forms of corrupted behavior to avoid them and facilitate the process of business establishment. For these reasons corruption can have a much greater impact on the establishment of new businesses in the countries with a lower degree of government effectiveness (Stanković \& Radenković-Jocić, 2017). Since this assumption has not been proven in the previous research, in this paper we will try to investigate the influence of corruption on the establishment of new businesses through a comparative analysis of the Western Balkans countries, which are 
characterized by a low degree of government effectiveness, and developed countries, which are characterized by a high degree of government effectiveness.

\section{HYPOTHESIS, METHODOLOGY AND MODELS}

The above mentioned studies suggest that corruption has become one of the leading global problems. However, corruption is not equally present in all countries in the world, so its influence on starting a business and economic development is not the same in all countries and regions. One of the reports that monitors the level of corruption at the national level is the Global Corruption Perceptions Index (CPI - Corruption Perceptions Index), monitored by Transparency International Organization (2016). Another frequently used indicator of corruption is contained in the reports of the World Bank on monitoring 'good governance" ${ }^{1}$ Good governance Index consists of five pillars: 1) Voice and Accountability, 2) Political stability and Absence of violence, 3) Government Effectiveness, 4) Regulatory Quality, 5) Rule of Law, and 6) Control of Corruption. In this paper, the data from the World Bank Report will be used because they are calculated and expressed based on the same methodology for the whole observed period of time. The Control of corruption pillar reflects perceptions of the extent to which public power is exercised for private gain, including both petty and grand forms of corruption. All countries are ranked according to the level of control of corruption, from 0 (lowest) to 100 (highest) rank. This aggregated indicator is calculated by combining a variety of indicators relating to the corruption which were obtained from a number of representative and non-representative data sources. The control of the corruption index for the Western Balkan countries as well as for the developed European countries is shown in Figure 1. In the analysis, we took five Western Balkan countries in transition and 20 European countries, whose level of corruption control index was the lowest in 2016.

\footnotetext{
${ }^{1}$ The ability of the state to provide those institutions that support growth and poverty reduction (often referred to as good governance) is essential to development. The later definition is within the same perception, in which governance is defined as '...the manner in which public officials and institutions acquire and exercise the authority to shape public policy and provide public goods and services'. Retrieved from: http://worldbank.org/governance/wgi/\#reports (10.11.2017.)
} 


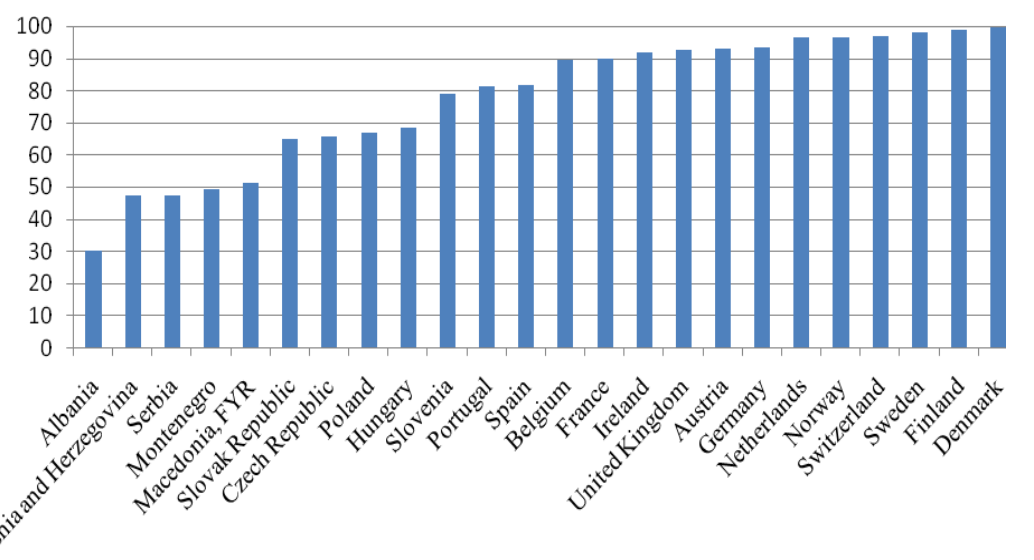

Figure 1. Control of corruption index of Western Balkan countries and the developed European countries in 2016.

Source: The World Bank, Worldwide Governance Indicators, http://databank.worldbank.org/data/reports.aspx?source=worldwide-governanceindicators (accessed on10.9.2017.)

As Figure 1 shows, developed as well as developing countries are not spared from corruption, but the level of corruption is not equal in all countries. The highest level of corruption (ie. the lowest level of corruption control index) is in the Western Balkans countries (Albania, B\&H, Serbia, Montenegro and FYR Macedonia), followed by the countries that have recently completed the process of transition (Slovak Republic, Czesc Republic, Poland, Hungary). The lowest level of corruption characterizes the majority of the most developed European countries. These data agree with the other authors' assumptions that corruption is less prevalent in the countries characterized by a higher level of political stability and a higher level of economic development. The presence of corruption, which involves the payment of different forms of rents, in order to obtain privileges, may increase the cost and uncertainty for entrepreneurs and enterprises. In addition to the increase of costs, it can reduce the return on investment in new businesses and can discourage potential entrepreneurs, as noted above in literature review. Bearing the above in mind, our first hypothesis is:

H1: Corruption has a major impact on the new businesses development measured by the number of newly established enterprises.

Previous studies also showed that regulation and administrative procedures are the key areas in which the interests of business people and civil servants sharply contrast each other. It is an area where a variety of opportunities for corruption occurs and indirectly affects the establishment of new businesses. The higher the number of procedures necessary for starting a new business, the greater the opportunity for public officials to 
undertake corrupt activities is, and the greater the likelihood that the potential founders of enterprises and entrepreneurs will engage in corruption. In other words, indirect impact of corruption on start-ups is greater in this situation. Bearing the above in mind, our second hypothesis is:

$\mathrm{H} 2$ : Corruption indirectly has the biggest impact on starting new business in the fields where the largest number of administrative procedures is present.

Report of the World Bank and other global reports show that the levels of corruption in individual countries are very different. Therefore, it can be expected that the impact of corruption on economic and social phenomena is different in different countries. The analysis will be carried out on a sample of the Western Balkans countries in transition and the developed European countries. The Western Balkans is seen as a region with high level of corruption. Corruption is seen as a major obstacle to greater investment in the region and for efficient operations. Accordingly, our third hypothesis is:

H3: The impact of corruption on starting a new business is greater in the Western Balkans countries in transition in compared to the developed European countries.

The methods of correlation and regression analysis will be applied for testing the validity of the above hypotheses. Dependent variable in the study is the number of new businesses registered per 1000 people, whose values are taken from the website of the World Bank. The control of corruption indexes included as an independent variable. These data are taken from the website of the World Bank in the report of Worldwide Governance Indicators. Since corruption affects starting up process also indirectly, in addition to control of corruption index, indicators illustrating countries' conditions for doing business from the World Bank "Doing Business Report" ${ }^{2}$ will be taken also into consideration as independent variables. Namely, these indicators from World Bank Doing Business Report relate to: starting a business, dealing with construction permits, getting electricity, registering property, getting credit, for the period from 2004 to 2016. We used the DTF data (Distance to Frontier) for each of these variables from Doing Business data base ${ }^{3}$. In this regard, the analysis

\footnotetext{
${ }^{2}$ All data on doing business indicators for all countries can be seen on: http://www. doingbusiness.org/data

${ }^{3}$ DTF (Distance to Frontier) measures the distance of each economy to the "frontier", which represents the best performance observed on each of the indicators across all economies in the Doing Business sample since 2005. An economy's distance to frontier is reflected on a scale from 0 to 100 , where 0 represents the lowest performance and 100 represents the frontier. Full description on methodology for calculation of DTF score can be seen on: http://www.doingbusiness.org/data/distance-to-frontier
} 
is based on 275 observations. Based on all this, an appropriate starting regression model is given below:

$$
\begin{gathered}
N B R=\beta_{0}+\beta_{1} C C+\beta_{2} S B+\beta_{3} D P C+\beta_{4} G E+\beta_{5} P R+\beta_{6} G C+\varepsilon ; \\
\varepsilon \sim N\left(0, \sigma^{2}\right)
\end{gathered}
$$

The variables included in the model are shown in the following table:

\begin{tabular}{|c|c|c|}
\hline Variable & $\begin{array}{l}\text { Variable } \\
\text { Type }\end{array}$ & Model \\
\hline New businesses registered (number) per 1000 people (NBR) & Dependent & All \\
\hline Control of Corruption (CC) & Predictor & All \\
\hline Starting a business (SB) & Predictor & All \\
\hline Dealing with Construction Permits (DCP) & Predictor & All \\
\hline Getting Electricity (GE) & Predictor & - \\
\hline Registering Property (RP) & Predictor & All \\
\hline Getting Credit (GC) & Predictor & - \\
\hline Western Balkan countries dummy & Predictor & M2 \\
\hline Control of Corruption * Western Balkan countries dummy & Predictor & M2 \\
\hline
\end{tabular}

Table 1. List of used variables

Source: Authors

For the purpose of examining the nature of the connection between new businesses registered, on the one hand, and corruption, on the other hand, as well as to verify the hypothesis that the relation between these phenomena differs significantly between Western Balkan transition countries and developed European countries, regression model was applied:

$$
\begin{gathered}
N B R=\beta_{0}+\beta_{1} C C+\beta_{2} S B+\beta_{3} D P C+\beta_{4} G E+\beta_{5} P R+\beta_{6} G C+\beta_{7} D+ \\
\beta_{8}(C C * D)+\varepsilon_{i} ; \\
\varepsilon_{i} \sim N\left(0, \sigma^{2}\right),
\end{gathered}
$$

where $D$ is dummy-variable, and coded 1 for Western Balkan countries, and 0 for developed European countries:

$$
D=\left\{\begin{array}{l}
1 \text { for Western Balkan countries, } \\
0 \text { for developed European countries }
\end{array}\right.
$$

The model attempts to predict changes in the dependent variable (New businesses registered per 1000 people), related to the direct and indirect impact of corruption in developing Western Balkan countries and developed European countries. The analysis uses standard multiple regression, entering independent variables into the equation at the same time.

The empirical aspect of this research is designed to explore impact of corruption on establishment of new businesses at the national level, based on the data provided by the World Bank for the period from 2004 
to 2016. Data is observed especially in respect of the countries in transition, belonging to the region of Western Balkan and 20 developed European countries. There were just 5 countries which Development Policy and Analysis Division of the Department of Economic and Social Affairs of the United Nations Secretariat (World Economic Situation and Prospects, 2017) classified as countries in transition. The countries which were included in the study are given in Table 2.

Table 2. Countries which were included in the study

\begin{tabular}{ll}
\hline Category & Country \\
\hline Western Balkan & Albania \\
Countries in transition & Bosnia and Herzegovina \\
& Macedonia, FYR \\
Montenegro & Serbia \\
Developed European Countries & Austria \\
& Belgium \\
Switzerland \\
Czech Republic \\
Germany \\
Denmark \\
Spain \\
Finland \\
France \\
United Kingdom \\
Croatia \\
Ireland \\
Hungary \\
Netherlands \\
Norway \\
Poland \\
Portugal \\
Slovak Republic \\
Slovenia \\
Sweden \\
\hline Source: Authors
\end{tabular}

\section{RESULTS AND DISCUSSION}

The research had two phases. First, we investigated the relationship between the corruption control index and the numbers of newly established enterprises per 1000 people using the method of correlation analysis. The results of correlation analysis are presented in Table 3 . The correlation is based on data for all 25 countries. 
Table 3. Correlations

\begin{tabular}{lccccccc}
\hline & NBR & CC & SB & DCP & GE & RP & GC \\
\hline NBR & 1.000 & & & & & & \\
&. & & & & & & \\
CC & .443 & 1.000 & & & & & \\
& $(.000)$ &. & & & & & \\
SB & .411 & .492 & 1.000 & & & & \\
& $(.000)$ & $(.000)$ &. & & & & \\
DCP & .274 & .817 & .517 & 1.000 & & & \\
& $(.000)$ & $(.000)$ & $(.000)$ &. & & & \\
GE & .028 & .633 & .422 & .549 & 1.000 & & \\
& $(.324)$ & $(.000)$ & $(.000)$ & $(.000)$ &. & & \\
RP & .274 & .425 & .379 & .454 & .426 & 1.000 & \\
& $(.000)$ & $(.000)$ & $(.022)$ & $(.002)$ & $(.000)$ &. & \\
GC & .063 & .019 & .305 & .272 & .034 & .394 & 1.000 \\
& $(.003)$ & $(.000)$ & $(.004)$ & $(.000)$ & $(.290)$ & $(.000)$ &. \\
\hline & & \multicolumn{7}{c}{ Source: Authors } & & &
\end{tabular}

As it is shown in the table 3 , there is directly, moderately strong (0.443) and statistically significant correlation between number of newly established enterprises and level of corruption control index. Since the index of corruption control was presented in points from 1 to 100 (where 1 represents the highest level of corruption, and 100 the lowest level of corruption) it means that the reduction of the level of corruption leads to an increase in the number of newly established companies, and vice versa, an increase of the level of corruption of the a country affects the cutback of the number of newly established enterprises. Also, the correlation between number of newly established enterprises and indicator related to starting a new business is moderately strong (0.411), and statistically significant. Additionally, there is a statistically significant correlation between the number of newly established enterprises and Dealing with Construction Permits (0.274) as well as with Registering Property (0.274), while correlation between Getting credit and Number of newly established enterprises is weak (0.063), as well as correlation between Getting Electricity and Number of newly established enterprises, but statistically insignificant for the latter. Because of that, these two variables were excluded from the regression model.

Also, table 3 shows very strong correlation between Corruption control and Dealing with Construction Permits (0.817), as well as between Corruption control and Getting Electricity (0.633). This means that corruption has exceptionally large impact on obtaining construction permits and obtaining electricity, which are very important when starting a business in new facilities. Also, there is a moderately strong correlation between Corruption control index and Registering property (0.425) as well as between Corruption control and conditions to Starting a new 
business (0.492). In other words, corruption has a great impact on every aspect important for starting and doing business, so one can conclude that indirect impact of corruption on starting a new business is also very high.

Table 4 shows the results for two basic regression models. Model 1 analyzes the impact of corruption on a number of newly-established firms (in all the countries in our sample). Model 2 analyzes the differences in the influence of corruption on a number of newly-established firms in the developing countries in the Western Balkans and developed European countries. The model includes dummy for the Western Balkans countries (The variables Getting Credit and Getting Electricity are excluded from the model, due to the fact that between them and New businesses registered per 1000 people there are extremely low, almost negligible correlation, and also bearing in mind that connection between New businesses registered per 1000 people and Getting Electricity is not statistically significant).

Table 4. Estimation results of Models (1) - (2) over period 2004-2016 (325 observations) $a$

\begin{tabular}{lcc}
\hline & Model 1 & Model 2 \\
\hline Constant & $-2.628^{* *}$ & $-2.589^{* *}$ \\
Control of Corruption & $.003^{* *}$ & .007 \\
Starting a business & $(.036)$ & $(.044)$ \\
& $.049^{* *}$ & $.048^{* *}$ \\
Dealing with Construction Permits & $(.045)$ & $(.038)$ \\
Registering Property & .006 & .007 \\
Western Balkan countries dummy & $(.068)$ & $(.090)$ \\
& $.013^{* *}$ & $.012^{* *}$ \\
Control of Corruption * Western Balkan countries dummy & $(.128)$ & $(.121)$ \\
& & $-1.946^{*}$ \\
R & $(-.499)$ \\
Adjusted ${ }^{2}{ }^{*}$ Standardized Coefficients Beta are between brackets & $-.047^{* *}$ \\
${ }^{*}$ Significant at 0.10 level. & $(-.557)$ \\
\hline Significant at 0.05 level. & .510 \\
\hline
\end{tabular}

In each of the models we found a direct positive and significant impact of corruption on a number of new businesses. Model 1 shows that a number of new businesses per 1000 inhabitants increase by 0,003 if the level of corruption control index increase by one index point. Since the higher index of corruption control means the lower corruption, we can conclude that a number of new businesses increase as the level of corruption decreases. Additionally, conditions for starting a new business as well as for registering a property, also have direct positive and significant 
impact on a number of new businesses. Coefficient of determination is 0.237 , which means that the model explains $23.7 \%$ of variance in the number of newly-established enterprises.

When we include in the model dummy variable for Western Balkan countries and the interaction that it has with Control of Corruption index (Model 2) we found that Rand adjusted $\mathrm{R}^{2}$ increases (0.510 and 0.241 , respectively). The model indicates that number of newly-established enterprises was less in the countries of the Western Balkans than in the developed European countries (the result for the West Balkans countries dummy is -1.946), while the impact of corruption on a number of new businesses in the Western Balkans countries is higher than in the developed countries of Europe. The impact can be written as $0.007-0.047 * 1$ (1 for Western Balkan countries dummy). Also, the interaction between the dummy Western Balkans countries and Control of Corruption is significant at the 0.05 level.

\section{CONCLUSION}

It can be concluded that corruption is becoming a serious problem that affects the economy and society in general. This paper has analyzed the impact of corruption on the establishment of new businesses through a comparative analysis of the Western Balkan developing countries (characterized by an unstable macroeconomic environment and high level of corruption) and the developed European countries (with a stable macroeconomic environment and far lower level of corruption).

It is shown that corruption has a statistically significant impact on the establishment of new businesses in all countries in the world and that this influence can be direct and indirect. Corruption increases the cost of establishment of new firms and reduces the income that can be used as incentives for start-ups. Therefore, because of corruption, some potential investors give up/reject the idea of starting a new business. Also, many people who have an aversion to bribery and other forms of corruption give up starting a new business, because for them, the awareness of the necessity of paying bribes creates a psychological barrier which discourages entrepreneurial initiatives. In addition, the indirect impact of corruption through its influence on the fulfillment of legal and administrative procedures to start a business, such as obtaining construction permits, getting electricity, loan approval, registering property etc., can be exceptionally significant. Our research has shown that the level of corruption is highest in the areas such as Obtaining a construction permit as well as Getting Electricity, which are necessary when a new business involves building new facilities. Also, our research has shown that the impact of corruption is much higher in the countries characterized by less regulated macroeconomic environment such 
as the Western Balkans countries than in the countries with more regulated institutional environment such as developed European countries.

Some of the key reasons for corruption in the Western Balkans countries are: non-transparent laws and regulations, inefficiency of administrative services (in charge of issuing permits and property registration), courts, customs authorities, the lack of severe sanctions for unethical behavior of employees in public institutions, and the like. To change the situation, it is necessary to implement a large number of different measures. First of all, measures and policies for the elimination of corruption as an obstacle to starting a new business should focus on introducing strict sanctions for abuse of power and promoting transparency and openness of public services.

A very important measure is the consistency of the government in implementing measures aimed at eliminating corruption. The government must demonstrate their commitment to fight corruption, both through adoption and implementation of various rules and regulations, stricter sanctions, personal example (the practice of public enterprises and transactions of local authorities), and by promoting the transparency of corporate social responsibility, etc. It is vital to gain confidence in institutions and encourage business people and employees in the public services to report cases of corruption.

Also, a very important group of measures is related to raising awareness of the harmful effects of corruption. An important role in this regard can be given to the media. The role of the media can be seen in providing support to relevant institutions and organizations that implement anti-corruption measures. Also, one of the possible measures could be to promote codes of conduct in business associations or industry sectors. This approach ensures that companies will not lag behind in relation to their competitors in the industry involved in corruption. Furthermore, given the whole range of standards, the impact on the business environment will be much higher. A useful measure could be the introduction of an anonymous phone line to report realized corrupt activities or attempts in their implementation. Significant support can come from clusters and other business associations of SMEs, which gather small and medium-sized enterprises in a particular geographic area. Business associations can help small and medium-sized enterprises in collecting information on reported acts of corruption, and in submitting complaints to committees in various industrial sectors. Non-governmental organizations can also help in the fight against corruption, by implementing research, publishing information, developing education, and raising awareness. These measures can help the Western Balkan countries build a more stimulating and stable environment that would encourage starting new businesses and economic development. 


\section{REFERENCES}

Aidt, T., \& Dutta, J. (2008). Policy Compromises: Corruption and Regulation in a Democracy. Economics and Politics, 20(3), 335-60

Ateljević, J., and Budak, J. (2010). Corruption and Public Procurement: Example from Croatia. Journal of Balkan and Near Eastern Studies, 12(4), 375-397.

Avnimelech, G., Zelekha, Y., \& Sarabi E. (2011). The effect of Corruption on Entrepreneurship. Copenhagen Business School, Denmark, Druid Society

Budak, J., \& Rajh, E (2011). Corruption as an Obstacle for Doing Business in the Western Balkans: A Business Sector Perspective, Ekonomski institut, Zagreb / The Institute of Economics, Zagreb, 5-20.

Campos, N., Dimova, R., \& Saleh, A. (2010). Whither corruption? A quantitative survey of the literature on corruption and growth. CEPR Discussion Paper No. 8140.

Campos, N., Estrin, S., \& Proto, E. (2010).Corruption as a Barrier to Entry: Theory and Evidence. CEPR Discussion Paper No. 8061.

Dreher, A., \& Gassebner, M. (2013). Greasing the wheels? The impact of regulations and corruption on firm entry, Public Choice, 155, 413-432.

Dzhumashev, R. (2014). Corruption and growth: The role of governance, public spending, and economic development, Economic Modelling, 37 (2), 202-215.

Grodeland, A., Berit, A., \& Aasland, A. (2011). Fighting corruption in public procurement in post-communist states: Obstacles and solutions. Communist and PostCommunist Studies, 44(1), 17-32.

Hanousek, J. \& Kochanova, A. (2016) Bribery environments and firm performance: Evidence from CEE countries, European Journal of Political Economy, 43, (14), 41-56.

Kaufmann, D., \& Vicente, P. (2005). Legal Corruption, http://siteresources.worldbank. org/INTWBIGOVANTCOR/Resources/Legal_Corruption.pdf (accessed on 10.9.2017)

Méon, P. G., \& Weill, L. (2010). Is corruption an efficient grease? World Development, $38(3), 244-259$.

Osuagwu, L. (2012). Conceptualization of Corruption in Business Organizations. American International Journal of Contemporary Research, 2 (5), 18-25.

Shaukat, H. (2004). Corruption and the Development. Journal of Development Policy and Practice, 1(1), 25-41.

Sobel, R. (2008). Testing Baumol: Institutional quality and the productivity of entrepreneurship. Journal of Busienss Venturing, 23, 641-655.

Staković, J., \& Radenković-Jocić, D. (2017). The Role of Business Environment in the Promotion of Investment Activities: Case Study of Cities and Municipalities in the Republic of Serbia. Teme, 41(2), 473-457.

Stefanović, S., Ivanović-Djukić, M., \& Janković-Milić, V. (2013). The Analysis of Key Challenges and Constraints to the Stability and Growth of an Entrepreneurial Sector in Serbia. Journal of Balkan \& Near Eastern Studies, 15 (3), 346-363.

The World Bank, Doing Business Data, http://www.doingbusiness.org/data (accessed on 10.9.2017.)

The World Bank, Worldwide Governance Indicators, http://databank.worldbank.org/data/ reports.aspx?source=worldwide-governance-indicators (accessed on10.9.2017.)

Transparency International Organization, World Economic Forum, 2016 www. transparency.org/news/feature/corruption_perceptions_index_2016 (accessed on 10.9.2017.)

Vial, V., \& Hanoteau, J. (2010). Corruption, manufacturing plant growth, and the Asian paradox: Indonesian evidence. World Development, 38(5), 693-705. 


\title{
УТИЦАЈ КОРУПЦИЈЕ НА ПОКРЕТАЊЕ НОВИХ ПОСЛОВА - КОМПАРАТИВНА АНАЛИЗА ЗЕМАЉА ЗАПАДНОГ БАЛКАНА И РАЗВИЈЕНИХ ЗЕМАЉА ЕУ
}

\author{
Винко Лепојевић, Маја Ивановић Ђукић, Сузана Стефановић \\ Универзитет у Нишу, Економски факултет, Ниш, Србија
}

\section{Резиме}

Последњих година, корупција постаје један од горућих проблема широм света, који утиче и на покретање нових послова, односно на развој предузетништва. О томе какав је утицај корупције на покретање нових послова у литератури постоје врло различити ставови и мишљења. Са једне стране, присутан је све већи број осуда које објашњавају изузетно негативан утицај корупције на све сфере друштва, па самим тим и на покретање нових послова. У том правцу, објашњава се да због корумпираности државни службеници, који су вођени личним користима, доносе одлуке које су супротне јавном интересу, чиме могу повећати трошкове оснивања нових предузећа, продужити време оснивања, подстаћи нелојалну конкуренцију, усмерити подстицајна финансијска средства у погрешне руке и на велики број других начина утицати дестимулативно на покретање нових послова. Међутим, постоје и тврдње да корупција може утицати и позитивно на покретање нових послова, јер „подмазивање” може скратити време и смањити трошкове оснивања нових предузећа.

Иако се ради о врло значајном елементу привредног развоја и врло актуелном проблему, утицај корупције на развој предузетништва није много проучаван у литератури. Такође, нема значајних емпиријских доказа да ли је веза између ових појава јака и статистички значајна. Зато је у овом раду анализиран утицај корупције на покретање нових послова. Пошто је ниво корупције врло различит међу земљама у овом раду, вршена је компаративна анализа утицаја корупције на покретање нових послова у земљама Западног Балкана и развијеним европским земаљама.

Испитивано је да ли корупција утиче директно и индиректно на покретање нових послова, на узорку од 20 развијених европских земаља и 5 земаља Западног Балкана применом хијерархијске регресије на основу временских серија података за период од 2004. до 2016. године. Зависна променљива био је број новооснованих предузећа на 1000 радноспособних становника. За праћење директног утицаја корупције коришћен је показатељ контроле корупције из извештаја Светске банке о индикаторима тзв. добре државне управе (Good governance). C друге стране, посредан утицај корупције праћен је преко елемената пословног окружења значајних за покретање посла које прати Светска банка и објављује у извештају „Doing business” (реч је о индикаторима: лакоћа покретања посла, добијање грађевинских дозвола, добијање прикључка за електричну енергију, регистрација имовине, добијање кредита).

Показано је да корупција има негативан и статистички значајан утицај на покретање нових послова и да је тај утицај много наглашенији у земљама које карактерише мање уређен макроекономски амбијент какве су земље Западног Балкана. Корупција је најзаступљенија у областима где је присутан највећи број административних процедура неопходних за покретање посла, као што су следеће: добијање грађевинских дозвола, регистровање имовине и добијање прикључака 
за електричну енергију. Да би се стање изменило и повећао број новооснованих предузећа и развој предузетништва, потребно је спровођење великог броја мера.

Као неке од могућих мера и политика за елиминисање корупције, као препреке за покретање нових послова, могу се навести: оштре санкције за злоупотребу службеног положаја, промовисање транспарентности и отворености јавних служби, преданост влада (нарочито у земљама Западног Балкана) борби против корупције (како усвајањем и имплементацијом различитих прописа и правилника, пооштравањем санкција тако и личним примером), промовисањем транспарентности друштвеноодговорног понашања итд. Такође, веома важна група мера везана је за подизање свести о штетном утицају корупције. Један од могућих начина може бити промовисање кодекса понашања у оквиру пословних удружења или сектора индустрије, као и активирање медија у ширењу информација о озбиљности проблема које ствара корупција. 